\title{
モデルアンサンブル予報による 2010年7月可児豪雨の予測可能性 \\ PREDICTABILITY OF THE HEAVY RAINFALL DISASTER AT KANI CITY IN JULY 2010 BASED ON MODEL ENSEMBLE FORECASTS
}

\author{
吉野 純 1 ・飯田 潤士 ${ }^{2} \cdot$ 安田 孝志 ${ }^{3}$ \\ Jun YOSHINO, Junji IIDA and Takashi YASUDA \\ 1正会員 理博 岐阜大学助教 工学研究科環境エネルギーシステム専攻 （テ501-1193 岐阜市柳戸1-1） \\ 2正会員 大日コンサルタント株式会社 地理空間情報部（テ500-8384 岐阜市藪田南3-1-21） \\ 3フェロー 工博 岐阜大学教授 工学研究科環境エネルギーシステム専攻（テ501-1193 岐阜市柳戸1-1）
}

The predictability of the heavy rainfall disaster at Kani City, Japan in July 2010 is investigated using a model ensemble approach which relies on the combination of 32 member ensembles obtained from multiple parameterizations in the mesoscale meteorological model PSU/NCAR MM5. The model is initialized using the 20-km resolution global analyses JMA GSM-GPV with and without the radar-data assimilation system developed by Yoshino et al. (2009). It is found that the multi-parameterization ensemble forecasts averaged by 32 members during 24 hours are very skillful in indicating the area of severe local storm activity, while each member deviates largely from the ensemble mean. Furthermore, the radar-assimilated ensemble forecasts enable us to more precisely predict the area of greatest rainfall potential, because the initial conditions used here realistically represent 3-dimensional distributions of cloud microphysical properties in the atmosphere.

Key Words : heavy rainfall, mesoscale meteorological model, model ensemble forecasts

\section{1. はじめに}

IPCC第4次報告書が警鐘を鳴らすように，今後，地球 温暖化の進行により大気中の水蒸気量の増大の結果とし て, 局地的な集中豪雨による災害頻度はより増加するも のと眯念されている1). その影響か, 近年, 梅雨期にな ると毎年のように，突発的かつゲリラ的な豪雨による被 害が各地で発生しており，2010年7月15日に岐阜県可児 市で発生した豪雨でも，降り始めからの雨量が $270 \mathrm{~mm}$ (可児市役所）に達し，可児川の汇濫により市道が最大 $6.2 \mathrm{~m}$ 水没し, 死者・行方不明者4名の惨事になった.

このような豪雨に対して，24時間程度のリードタイム を確保してピンポイントに発生箇所を予測できるならば, 警報伝達や避難誘導などのソフト対策に留まらず，大型 土のうや鋼矢板などによる応急的なハード対策も可能と なり，効果的かつ即効性のある防災・減災対策が実現で きると期待される。しかし，残念ながら現状の気象予報 技術では，それを実現するだけの十分な技術レベルと実 績には到達しておらず，依然として多方面からの手探り が続いている，例えば，気象庁レーダーに基づく運動学
的手法による短時間予報は2)，時間・空間的に高分解能 な降雨予測を実現し，水工学分野においても広く活用さ れているが，6時間以内の予報期間が精度的に限界であ $\eta^{3)}$, 対策に必要な十分なリードタイムを確保すること が困難である. 一方で，気象モデルに基づく力学的手法 による短期予報は4)，より長い予報期間を確保できるこ とが利点ではあるが，初期值やモデルの不完全性に起因 するカオス的挙動により, 豪雨をもたらす積乱雲構造を 時間・場所と共に正確に決定論的に予測することは困難 を極める5), 6).

このような力学的手法に基づいた豪雨予測を，実用レ ベルへと発展させるためには，気象モデルによる「アン サンブル予報」が解決策の1つになると考えられる.ア ンサンブル予報とは, 複数の数值予報の集合（アンサン ブル）を統計的に処理して最も確からしい予報を得る手 法であり，初期值アンサンブル，モデルアンサンブル， 境界值アンサンブル，及び，外力アンサンブルといった 多種多様な集合の取り方がこれまでに提案されている゙． 今日まで，1週間や1ケ月といった中長期予報（全球モデ ル）に対するアンサンブル予報の運用実績はめざましい ものがあるが7), 8), 短期予報（領域モデル）に対する適 


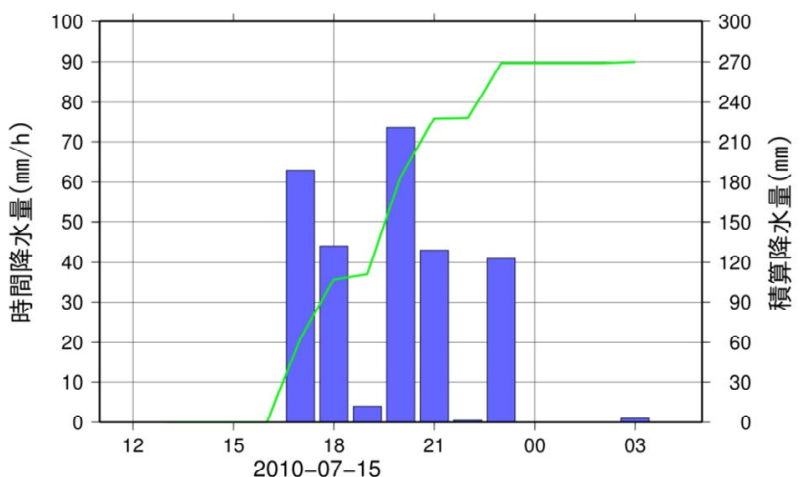

図-1 可児市役所における時間降水量（棒グラフ）と降り始 めからの積算雨量 (実線) の時系列（2010年7月15 日午前9時〜16日午前9時）

用実績は国外では散見されるものの9)，メソ現象，特に 豪雨などの顕著現象を対象としたアンサンブル予報につ いては国外も含めて十分な検討がなされているとは言い 難い.

そこで本研究では，モデルアンサンブル予報の一種で あるマルチパラメタリゼーション法をメソスケール気象 モデル PSU/NCAR MM $5^{10}$ に対して適用することで，全 32メンバーからなるアンサンブル予報を行い，2010年7 月可巟豪雨に関する予測可能性について検討する. また， モデルアンサンブル予報に入力する初期值の高精度化が 豪雨発生箇所の事前予測に如何なる影響を与えるかにつ いても検討を行う。

\subsection{0年7月可児豪雨について}

2010年7月15日の夕方から16日未明にかけて，本州付 近に停滞した梅雨前線や日本海を北東心寸る低気圧に向 かって非常に湿った空気が流れ込んで前線活動が強まり， 岐阜県中濃地方や東濃地方を中心に猛烈な大雨となった。 気象庁の観測によると，24時間雨量では伽藍で233mmを， 1時間雨量では多治見で83.5mmを記録し，いずれも観測 史上1位を更新した．可児市役所での観測では，降り始 めからの総雨量が270mmを記録し（図-1），可児川の水 位が急激に増大し, 午後8時すぎには土田で汇濫した。 これによって，40台を超えるトラックや乗用車が一気に 押し流される惨事となり，名鉄広見線と交叉寸る市道の アンダーパスでは最大 $6.5 \mathrm{~m}$ 冠水し, 死者・行方不明者 4 名の被害となった。岐阜県と岐阜地方気象台が土砂災害 警戒情報を発表した午後 6 時の時点では，既に切迫した 状況にあり，対応の遅れが被害の拡大を招いた ${ }^{11)}$.

図-2は，気象庁全国合成レーダーデータによる2010年 7月 15 日午前 9 時汃翌午前9時の 24 時間積算雨量の分布 を示す．可児川流域を日雨量 $200 \mathrm{~mm}$ 以上の領域がすっぽ りと覆っており, その形状から, 豪雨をもたらした降水
システムは南西一北東方向に走向を持つ停滞性のテーパ リングクラウドによってもたらされたものと推測される. 気象庁GPVデータやアメダス観測データより, 周辺地形 の影響を受けることで南よりの気流が収束し，中部山岳 によって強制上昇が生じることで降水システムは強化さ れ, この降水システムの南西端から次々と積乱雲が発生 したために持続的な大雨に繋がったと推測される.

\section{3. 数値計算の手法}

本研究では，この可児豪雨を対象として，メソスケー ル気象モデルMM5を使用し，マルチパラメタリゼー ション法に基づくアンサンブル予報を行う。ここでは, その数值計算手法の概要について解説する.

\section{(1) メソスケール気象モデル PSU/NCAR MM5}

本研究で使用寸る数值予報モデルMM5は, 完全圧 縮・非膨張系・非静力学平衡の領域メソスケール気象モ デルである ${ }^{10}$. 物理過程（パラメータリゼーション）と しては, 雲微物理過程, 積雲刘流過程, 大気境界層過程, 大気放射過程，地表面過程，及び，浅い対流過程を考慮 でき，それぞれ多数の計算スキームから選択可能である. 計算領域としては, 図-3に示寸ように, 岐阜県を中心と

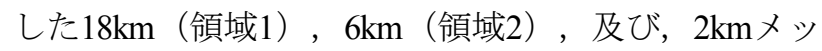
シュ（領域3）の計3領域からなる2-wayネスティング格 子を設定する.

\section{(2) マルチパラメタリゼーション法}

パラメタリゼーションとは，モデル格子間隔規模以下 の現象の効果を分解可能な現象から推定し，モデル格子

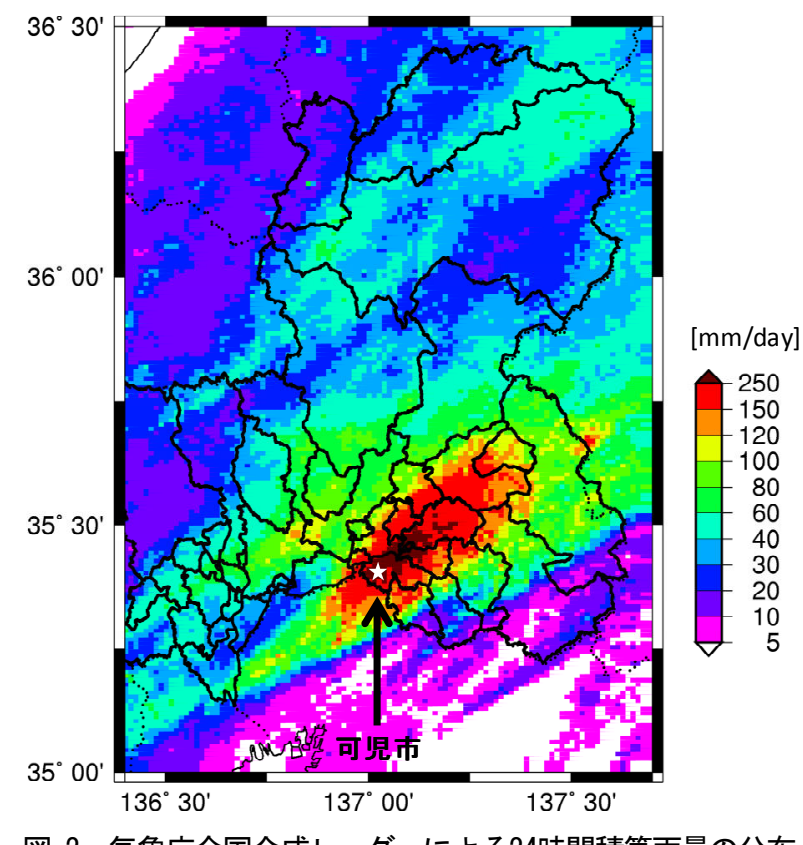

図-2 気象庁全国合成レーダーによる24時間積算雨量の分布 （2010年7月15日午前9時 16日午前9時） 


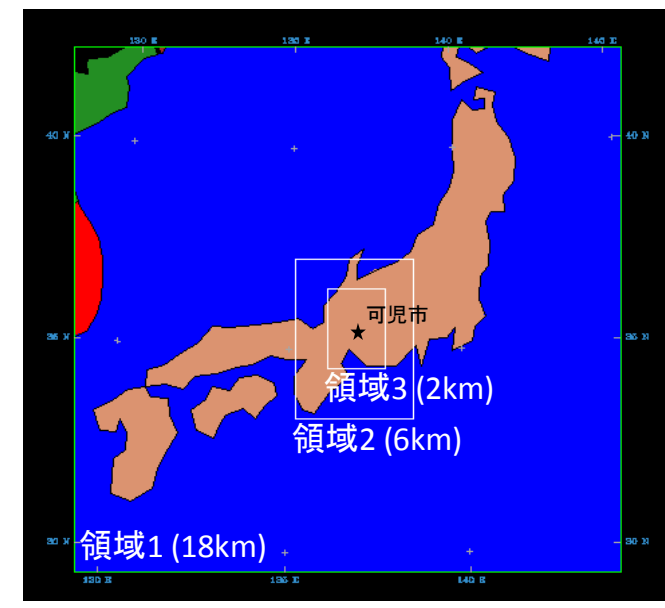

図-3 メソスケール気象モデルPSU/NCAR MM5の計算領域.

で与えられる変数に反映させるためのものであり， MM5には多種多様な計算スキームが実装されている. 一般的に，各種のパラメタリゼーションには，過去の観 測等に基づく值がパラメータとして導入されている.こ れらの值は，多くの事例で最適な值であったとしても， 数值積分毎に常に最適な值であるとは限らず, この差が 数值予報にランダムな誤差を引き起こす可能性がある. 特に，非線形効果の大きな豪雨発生時には，これらパラ メータに対する鋭敏な依存性がある.このような誤差を 統計的に処理するためには，複数の数值予報モデルの集 合を使ったアンサンブル予報, すなわち，「モデルアン サンブル予報」が解決の糸口になる可能性がある.これ によって，個々の決定論的予報にひそむノイズ（ランダ ム誤差）を，多数のモデルの平均を取ることで取り除き， 有意なシグナルのみを抽出できるようになる. アンサン ブル平均予報の精度は，個々の決定論的予報の平均精度 を上回ることが理論的に知られており，アンサンブルメ ンバー数を増やすことで予報誤差をより軽減できること も実証されている゙.

モデルアンサンブル予報にも複数の種類があるが，本 研究では，「マルチパラメタリゼーション法」を採用す る.これは，1つもしくは複数の物理過程において異な る計算スキームを適用した数值予報モデルの集合を使う 方法であり，基礎となる数值予報モデルは1つで済むこ とから，本研究のようにMM5を用いてアンサンブル予 報を行う際に最適であると言える.アンサンブルメン バーの構成方法について定石はなく，モデル摂動を経験 的かつ試行錯誤的に決定する必要がある゙).

\section{(3) 数値計算の設定条件}

本研究では，MM5によるマルチパラメゼーション法 に基づき, 全32メンバーからなるモデルアンサンブル予 報を実施する．積雲対流過程（領域1のみ）に対しては4 種類のスキーム（1)Anthes-Kuo，(2)Grell，(3Betts-Miller, (4)Kain-Fritsch)，大気境界層過程（全領域）に対しては 2種類のスキーム（1)Burk-Thompson, (2)Eta)，大気放
射過程（全領域）に対しては2種類のスキーム（1)Cloud， (2)CCM2），浅い対流過程（全領域）には1種類のス キームの入り切り（11on, (2off) を組み合わせることに より全32アンサンブルメンバーを構成している．特に, 領域1における積雲対流過程は, 豪雨現象に直接的に影 響する物理過程であることから，これに起因するランダ ム誤差の不安定成長は，領域3における豪雨予測にまで 大きく影響するものと推測される．豪雨に直接的には関 係しないその他の物理過程によっても, ホワイトノイズ 状の微小なランダム誤差が強い非線形効果によって成長 し，豪雨予測の結果に少なからず影響するものと考えら れる. 尚, 雲微物理過程についても複数のスキームが存 在するが，非現実的な素過程を含むものがあったり，計 算効率の低いものがあったりと, 精度面や実用面におい てアンサンブル予報に不向きなスキームが大半である. 本研究では，十分に詳細な素過程を考慮でき，尚かつ, 多量の予報に堪えられるだけの高い効率性を有する唯一 のスキーム「Schultzスキーム」を全領域に固定して適用 している ${ }^{12)}$. これら全32メンバーは，モデルの予報期間 (1メンバーあたり計48時間予報），計算機規模（計40 コアOpteron280 2.4GHz)，CPU時間（1メンバー・1コア あたり約6時間）などを勘案して設計されており，現業 予報システムとして運用可能な最大限度のメンバー数と なっている．各国の現業予報で採用されているアンサン ブル予報のメンバー数と比べても遜色はない.

MM5に入力する初期值・境界值には，気象庁GSMGPV日本領域（20kmメッシュ）を使用し，初期時刻 2010年7月14日午後9時（日本時間）から48時間予報をそ れぞれ実施した。ただし，1）気象庁GSM-GPVをそのま ま内挿して初期值とする予報（以降，同化なし）と，2) 気象庁GSM-GPVに対してレーダーデータ同化を適用し て初期值とする予報（以降，同化あり）の2種類を実施 する. 前者については，初期時刻に雲微物理量はゼロ設 定としているが，一方で，後者については，初期時刻に 領域1に対して気象庁全国合成レーダーデータを同化す ることで雲微物理量の3次元初期分布をより高精度に与 えることができる.このレーダーデータ同化は，位置誤 差修正法に基づき，「テンプレートマッチング法」と

「CIP移流スキーム」の組み合わせによって構成され, より高精度な降水量予測を実現している ${ }^{13)}$ 。これら異な る初期值を入力することで，それぞれにモデルアンサン ブル予報を実施し, 初期值高精度化が豪雨予測に与える 影響についても考察する.

\section{4. 結果と考察}

\section{(1) モデルアンサンブル予報による豪雨の予測可能性}

まず，同化なしのモデルアンサンブル予報の結果から， 可巟豪雨の発生に関する予測可能性について検討する. 
図-4は，全32メンバーの各々の24時間積算雨量（2010 年7月 15 日午前9時〜 16 日午前9時）の分布を示す. 多数 のアンサンブルメンバーから構成されるにも拘わらず, メンバー間で一致した分布を示すことは一切なく，豪雨 時には極めて強い非線形による不安定成長が卓越してい たと推測される. 大気境界層過程や大気放射過程といっ た降雨現象に直接関係しないパラメタリゼーションの選 択の違いによって，予測結果に大きな差異が生じている 点からも，場は極めて不安定でランダム誤差が増大しや すい環境にあったと考えられる，メンバーの中で，レー ダー観測（図-2）と完全に一致しているものはなく，更 に，可児市において豪雨となっているものも限られてい る.ただ，領域 3 内で豪雨が全く発生していないメン バーは1つもなく，また，可児市の近隣の異なる地域で 豪雨となるメンバーが多数を占めることから，アンサン ブル予報の誤差の大部分は豪雨域の位置誤差として表れ ていると考えられる．これらの結果から，仮に完全な初 期值が存在したとしても，気象モデルの不確実性に起因 寸る誤差の非線形による不安定成長の効果も決して無視 できず，やはりゲリラ的な豪雨の決定論的な予測は不可 能であると言える.

しかし，このような全 32 メン゙ーの 24 時間積算雨量 に対してアンサンブル平均とスプレッドを評価するこ とで，図-5のような結果が得られる。ここで，アンサ
ンブル平均とは, アンサンブル予報の結果として統計 的に最も実現する可能性の高いランダム誤差を取り除 いた推定值と見なすことができ，スプレッドとは，決 定論的予報のばらつきの大きさ（標準偏差），つまり， 決定論的予報の変動幅の程度と見なすことができ，ア ンサンブル平均が大きくスプレッドが小さいほど統計 的信頼度が高いと言える. アンサンブル平均の分布が 示すように，全体的に平滑化され絶対值としては大き く減じられてしまっているが，可児市を含む地域一帯 に明瞭な值のピークが出現している点が特徵的である。 奥三河地方にもピークが出現しており, 必ずしもアン サンブル平均の高い地域で豪雨が発生するとは言えな いが，本研究のモデルアンサンブル予報により，可児 豪雨の発生箇所を24時間前にある程度予測可能であっ たものと窥える．また，スプレッドの分布が示すよう に，アンサンブル平均の大きな地域では，スプレッド も大きくなる傾向にあり，個々の決定論的予報の信頼 性は低いと考えられる。しかしながら，可児市付近で は，アンサンブル平均が大きいにも拘わらず，アンサ ンブル平均の大きな他の地域と比べて相対的にスプ レッドが小さくなる傾向にあることから，他の地域に 比べて豪雨発生の可能性は一貫して高く, その信頼度 も高かったと言える.このことは，可児市付近では， 周辺地形の影響を受けて降水システムが定在的に強化
(1)(1)(1)(1)

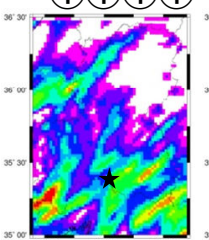

(2)(1)(1)

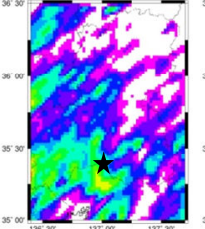

(3) (1) 11

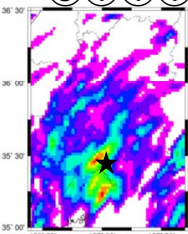

$$
\text { (4) (1) (1) }
$$

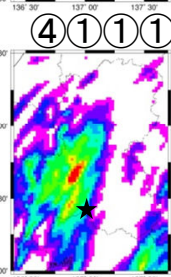

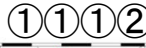

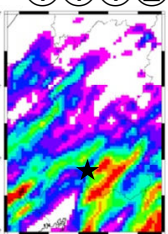

(2) (1) (1) 2

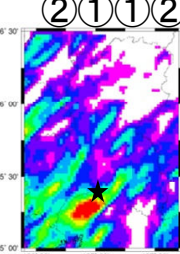

(3) (1) (1)
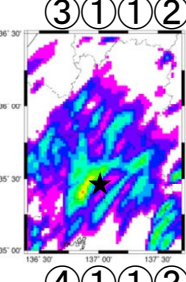

(1)(1)(2)(1)

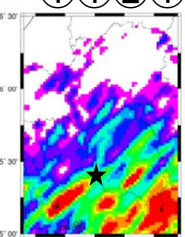

(2) (1)(2) 1

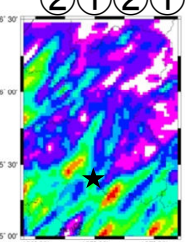

(3)(1)(2) (1)

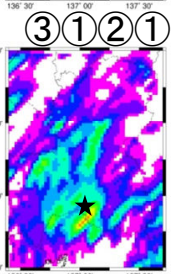

(4) (1)(2) 1
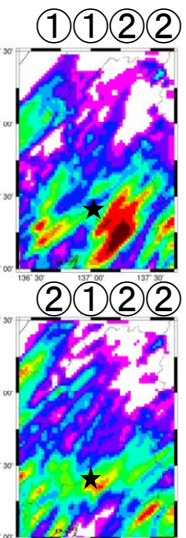

(3) (1) 2
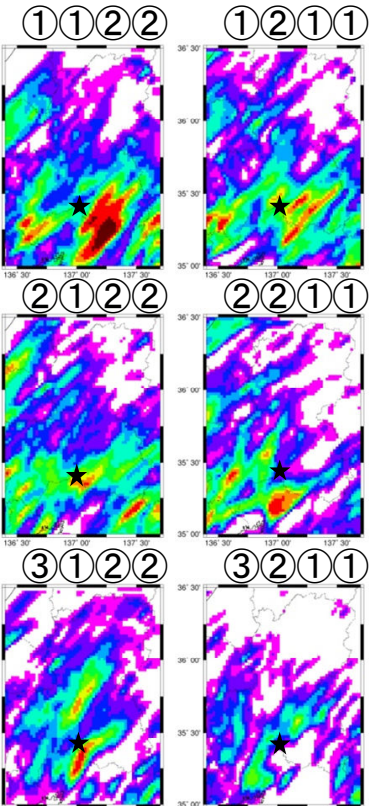

(1)(2)(2)
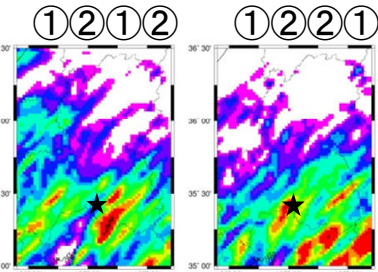

(1)(2)(2)

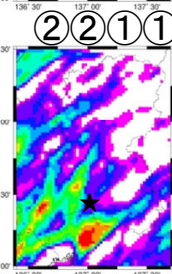

(3) (2) (1) 1
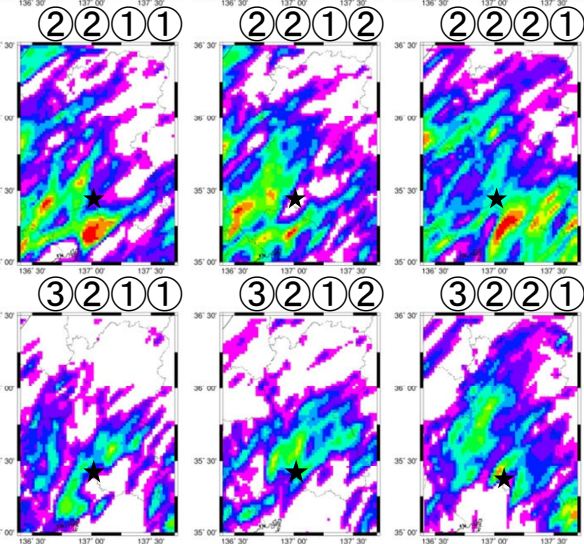

(3) (2) (2)
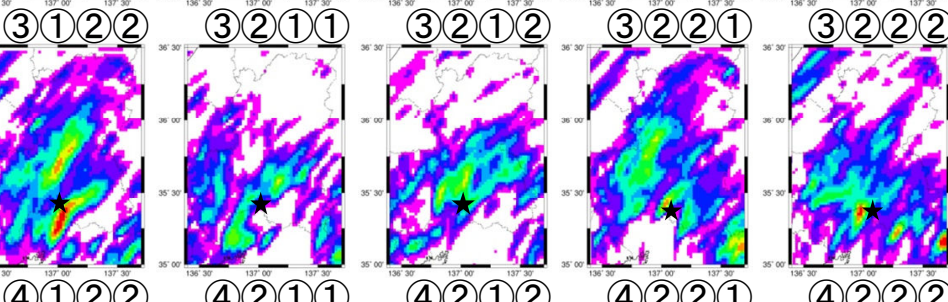

(4)(2)(2)(1)

(4)(2)(2)
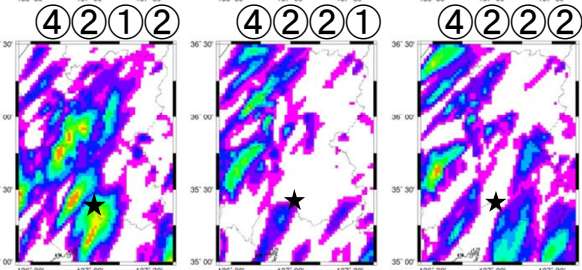

図-4 全32アンサンブルメンバー（同化なし）の各々の24時間積算雨量の分布（図上の数字は，左から順に積雲対流過程，大気 境界層過程，放射過程，および，浅い対流過程のそれぞれの種類を示す）。星印は可児市役所の位置を示す 

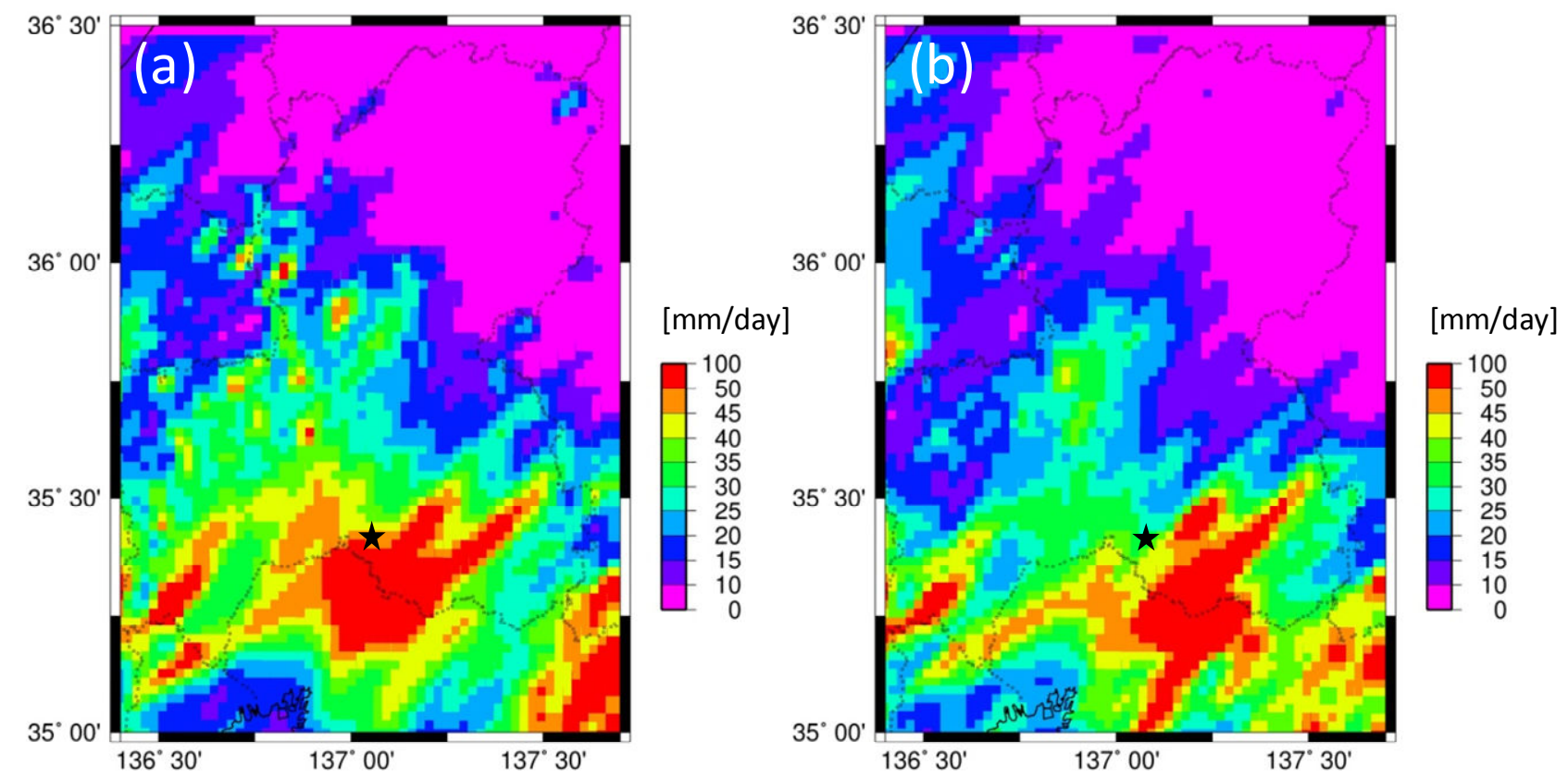

図-5 全32アンサンブルメンバー（同化なし）の日積算雨量の (a) アンサンブル平均值と (b) スプレッド（ 2010年7月15日午前 9 時〜16日午前9時）．星印は可児市役所の位置を示す．
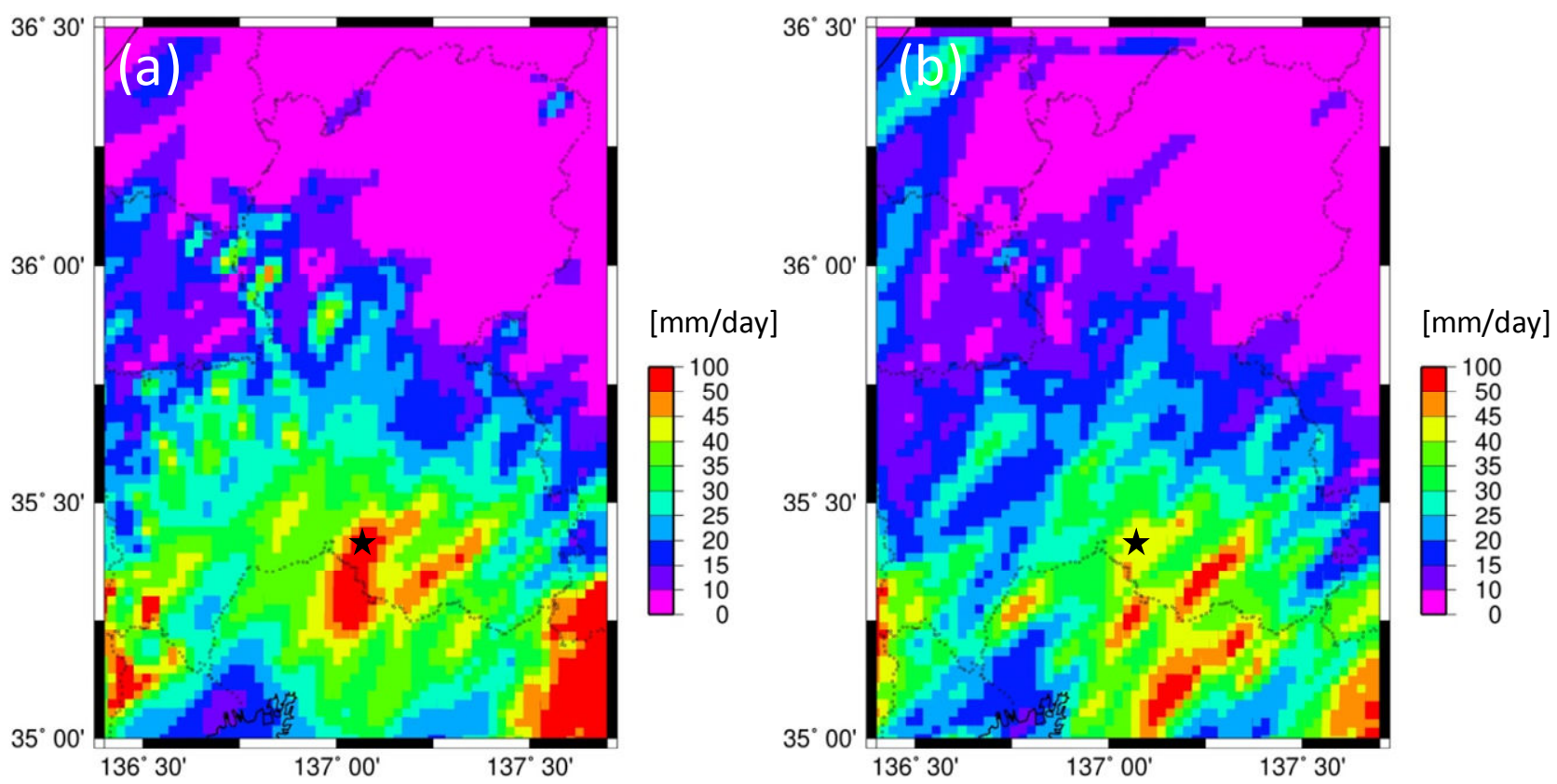

図-6＼cjkstart全32アンサンブルメンバー（同化あり）の日積算雨量の (a) アンサンブル平均值と (b) スプレッド（ 2010年7月15日午前 9 時〜16日午前9時）．星印は可児市役所の位置を示す．

されやすい環境にあったことを示唆する結果である.

以上の結果より，気象モデルによりゲリラ的な豪雨の 決定論的に予報することは極めて困難であるものの，本 研究で提案するマルチパラメタリゼーション法の採用に より，豪雨発生箇所を24時間前にある程度の確度の下で 予測できる可能性が明らかとなった。

\section{(2) 初期値高精度化による豪雨予測への影響}

次に，同化なしと同化ありのモデルアンサンブル予報
の結果の比較から, 初期値高精度化による豪雨予測に及 ぼす影響について考察する.

図-6は，同化ありのモデルアンサンブル予報による全 32 メンバーの 24 時間積算雨量に対するアンサンブル平均 とスプレッドの分布を示す. 同化なしの結果（図-5）と 比較して, 同様に強い非線形効果が卓越していたことが 分かるが，アンサンブル平均のピークは，可児市を中心 としてより絞られて出現していることが見て取れる。こ のことは，MM5の初期值高精度化により，より高精度 
な豪雨発生箇所の事前絞り込みが可能であることを意味 している．スプレッドについても，同化なしの結果（図 -5）と比較して，全体的に小さな值を示しており，全体 的に決定論的予報の信頼性は向上していると見なすこと ができる.アンサンブル平均のピークは可児市付近のみ ならず奥三河地方にも存在しているが，可児市付近では 周囲に比べてスプレッドが比較的小さく，地形の影響を 受けやすいためか, 周囲に比べて一貫して豪雨発生の可 能性が高い状態にあったと見なせる．MM5の初期值に 対してレーダーデータ同化を適用し，高精度な雲微物理 量の3次元分布を与えることで，予報中の降雨域の系統 的な位置誤差を軽減できたために，豪雨予測の高精度化 に繋がったと考えられる ${ }^{4)}{ }^{13)}$. つまり，アンサンブル予 報による豪雨予測の更なる高精度化のためには，単にモ デルの持つ不確実性のみならず，初期值の持つ不確実性 をも考慮して，更なる初期值高精度化や初期值アンサン ブルをも組み合わせてゆく必要があると言えるだろう。

以上の結果より，レーダーデータ同化に基づく初期值 高精度化によって，モデルアンサンブル予報による豪雨 発生箇所の予測可能性は一段と向上寸ることが明らかと なった.

\section{5. 結語}

本研究では, メソスケール気象モデルMM5を用いた モデルアンサンブル予報により，2010年7月に発生した 可児豪雨の予測可能性について検討した。 モデルアンサ ンブル予報の際には，MM5において選択可能な種々の 物理過程の計算スキームを組み合わせることで全 32 メ バーからなる48時間予報を実施し（マルチパラメタリ ゼーション法），それらの24時間積算雨量に対するアン サンブル平均やスプレッドを評価することにより，可児 豪雨における豪雨発生箇所との対比を行った.

その結果, 24時間積算雨量であってもアンサンブルメ ンバー間のばらつきはかなり大きく, 豪雨をもたらした システムには強い非線形効果が卓越しており, 個々の決 定論的予報に対寸る信頼性は高くないことが明らかと なった. 一方で, 全32メンバーのアンサンブル平均をと ることによって, 個々のメンバー間の予報誤差が打ち消 し合うことで，可児市近傍における豪雨発生箇所を24時 間前にある程度の精度で予測することが可能となり，本 手法の有用性を実証できた. 更に, モデルアンサンブル 予報に用いられる初期值に対してレーダーデータ同化を 適用することで，より高精度な豪雨発生箇所の事前絞り 込みが可能になることも明らかとなった。 モデルアンサ ンブル予報の際には，単にモデルの不確実性を考慮する のみならず，用いる初期值の不確実性をも考慮してゆく 必要性があると結論付けられた。

本研究によるモデルアンサンブル予報とレーダーデー
タ同化の組み合わせたシステムを運用することにより， 24時間前に高精度な豪雨発生箇所の予測が実現されるな らば，特に，降雨から災害発生までの時間が短い中小河 川の洪水汇濫, 低平地の内水汇濫, がけ崩れに対するリ アルタイムリスクマップの作成が可能となり, 豪雨発生 前の防災・減災のための效果的な応急対策が可能になる と期待される．本手法による更なる事例検証の積み重ね が望まれる.

謝辞 : 本研究は, 国土交通省建設技術開発費補助金によ る成果の一部であることを，ここに付記する.

\section{参考文献}

1) Kimoto, M., Yasutomi, N., Yokoyama, C. and Emori, S.: Projected changes in precipitation characteristics around Japan under the global warming, SOLA, Vol. 1, pp. 85-88, 2005.

2) 椎葉充晴, 高棹玩馬, 中北英一 : 移流モデルによる短時間降 雨予測の検討，水工学論文集，Vol.28，pp.423-428，1984.

3) 和田一範, 川㟝将生, 冨澤洋介 : 河川の高水管理における予 測降雨情報の適用性に関する考察, 水文・水資源学会誌,

Vol. 18, pp. 703-709, 2005.

4) 吉野純, 野村俊夫, 片山純, 木下佳則, 安田孝志 : メソ気象 モデルMM5によるピンポイント24時間降水量予測の精度に つい, 水工学論文集, Vol. 52, pp. 325-330, 2008.

5) Lorenz, E. N.: Deterministic nonperiodic flow, J. Atmos. Sci., Vol. 20, pp. 130-141, 1963.

6) 気象庁予報部：アンサンブル技術の短期・長期予報への利用, 2006.

7) 萬納寺信崇, 前田修平 : 1ケ月予報のための数值予報モデル, 平成13年度季節予報研修テキスト, pp. 35-47, 2001.

8) Mylne, K. R., Evans, R. E. and Clark, R. T.: Multi-model and multianalysis ensembles in quasi-operational medium-range forecasting, Quart. J. Roy. Meteor. Soc., Vol. 128, pp. 361-384, 2002.

9) $\mathrm{Du}$, J. and Tracton, M. S.: Implementation of a real-time short-range ensemble forecasting system at NCEP: an update, Proceedings on 9th Conference on Mesoscale Processes, Vol. 9, pp. 355-356, 2001.

10) Dudhia, J.: A nonhydrostatic version of the Penn State-NCAR mesoscale model: Validation test and simulation of an Atlantic cyclone and cold front, Monthly Weather Review, Vol. 121, pp. 1493-1513, 1993.

11) 岐阜地方気象台: 平成22年7月 11 日〜 16日の梅雨前線によ る大雨に関する岐阜県気象速報, 2010 .

12) Grell, G. A., Dudhia, J., and Stauffer, D. R.: A description of the fifth-generation Penn State/NCAR mesoscale model (MM5). NCAR Tech. Note NCAR/TN-3981STR, 1994.

13) 吉野純, 野村俊夫, 安田孝志 : 降水量予測の精度向上のた めの位置誤差修正法に基づくレーダーデータ同化システムの 開発，水工学論文集，Vol. 53，pp. 379-384， 2009.

(2010.9. 30受付) 